\title{
The design of ceramic wall hanging products for café interior with an industrial-style theme in the city of Tasikmalaya
}

\author{
Adhi Rahmadi Nugraha ${ }^{1 *}$,Gita Winata ${ }^{2}$
}

\author{
${ }^{1}$ Institut Teknologi Bandung, Indonesia \\ ${ }^{2}$ Institut Teknologi Bandung, Indonesia \\ *Corresponding author. Email: adhirahmadinugraha@gmail.com
}

\begin{abstract}
The increasing culinary industry in Indonesia has made many culinary entrepreneurs such as cafes and restaurants make various innovations and improvisations due to the high level of competition. The habit of urban communities that use cafes and restaurants as an alternative space for interaction makes the function no longer only for enjoy the food provided. Building design styles such as architecture and interiors now strongly influence attracting consumers who prioritize aesthetics, comfort, and the need for interaction space. This research is performed to produce a Sustainable ceramic wall hanging product that aims to increase the aesthetic value as part of the room's interior that can increase the attractiveness of industrial-style cafes and restaurants. This research uses a practice-led research method based on a creative model called iterative cycle web, a design cycle flow that starts with idea generation, develops chosen ideas, theorizes ideas, and develops techniques as method and application of theories and techniques to new creative work. This research shows the creative process in designing a product through an approach and understanding related to the characteristics of Industrial style and various exploration processes to find the most suitable design. The design of industrial-style ceramic wall hanging interior products is performed through a design process by adapting geometric shapes and basic colors, which are characteristics of the Industrial interior theme. The gypsum molding production technique is very suitable for producing geometric shapes and producing precise and repeatable module shapes. The product design results can be arranged and composed according to the needs to increase the aesthetic value and attractiveness of the room.
\end{abstract}

Keywords: Industrial style, Interior, Ceramic, Practice-led Research

\section{INTRODUCTION}

The culinary industry in Indonesia continues to increase from year to year. Based on data from the ministry of tourism and creative economy, culinary is one of the sub-sectors contributing the largest Gross Domestic Product at $43 \%$ in 2020. The culinary industry, such as cafes and restaurants, is growing rapidly in big cities [1]. One example is the City of Tasikmalaya, which, based on data from the Central Statistics Agency, stated that the growth of food and beverage business accommodation had reached $5-9 \%$ in the last 5 years. The increase in the culinary industry affects the level of competition between each business, which makes culinary entrepreneurs continue to innovate and improvise. Adaptation of industrial- themed building design is an architectural and interior innovation that is now the most popular choice, especially in providing interaction facilities in the commercial and culinary industries such as cafes and restaurants.

A cafe or restaurant is one part of the public space often visited by urban communities as an alternative interaction space for families, relationships, or other formal activities. The interaction space is getting smaller in urban areas, and the urge to find a new atmosphere amidst the density of activities, making urban people look for interaction space from a workspace or residence in public places [2]. The function of cafes and restaurants that keep popping up in urban areas is now no longer only for eating various 
types of food and drinks on offer but also providing facilities for interaction such as gatherings, meetings, hangouts, to other activities such as doing assignments or a place for recreation. The increasing number of cafes and restaurants that compete to attract the attention of their consumers makes business people do various ways, one of which is to design the interior of the building using a certain theme as attractively as possible to build a pleasant atmosphere as part of the adjustment and improvement of services for consumers [2].

The industrial style, which is now increasingly being used by cafes and restaurants, was chosen because the interior and building themes can provide an urban feel and atmosphere with aesthetic value [3]. The theme of building design has a significant influence on the attractiveness and interest of visiting consumers who are now starting to prioritize aesthetics and comfort and the need for interaction space as part of the facilities needed in cafes and restaurants [4]. This research aims to produce a ceramic product design to increase the aesthetic value as part of the room's interior to increase the attractiveness of industrial-style cafes and restaurants. The researcher chose ceramic material because it can produce durable products adapted to Industrial themes by utilizing a customizable production process. The use of practice-led research methods allows researchers to explore and mature ideas by testing and applying theory through practice. The process of selecting ideas can produce several possible opinions, descriptions, or word formations carried out through in-depth research developed and issued through comprehensive research publications.

\section{INDUSTRIAL STYLE}

The industrial style in buildings that include architecture and interiors first appeared in 1950 in Europe. Many unused factory buildings at that time were transformed into decent housing. Industrial style is based on industrial production and civilization, which contains various industrial symbols and fulfills contemporary lifestyle and aesthetic needs of spatial art forms [5]. The industrial-style architecture utilizes the original construction of a building that initially had the main function of accommodating and facilitating all industrial activities. Industrial style refers to aesthetic and design trends by focusing on raw materials or basic materials such as cement, bricks, concrete, and steel as part of the building's identity. Exposure is used on the structural and mechanical parts of the building. The use of economical construction methods by not hiding or disguising parts of the building with finishing makes this design style more attractive to the public, starting from apartments, commercial spaces, and even modern houses [6]. The concept in industrial-style design has a masculine tendency shown through materials in parts of the building that are deliberately exposed to show the original character of the materials. The appearance that emerges from the design results gives a rough impression and the impression of monochromatic colors such as black, gray, white, to brown that appear naturally from the architectural and interior materials used [7].

Building structures that are left unfinished such as exposed brick walls or cement walls, give a strong impression that is identical to the Industrial building style, including the furniture inside that accentuates the original color. The Industrial Room design, which has a strong connection with the technical background by displaying the material as it is, gives a unique and attractive industrial feel for its users. The appearance that shows an airy impression is a characteristic of this design style which is very useful in public spaces because it gives a minimalist, firm, and masculine impression and a relaxed and not hierarchical atmosphere [8].

\section{INTERIOR BASIC ELEMENTS}

An interior room is composed of basic elements that will give rise to an impression, style, and theme in its composition. The choice of construction materials and products such as indoor furniture will affect the resulting characteristics. The interior can achieve harmonization and balance by applying several basic elements of interior design, including line, shape, plane, light, colour, pattern, texture, and space [9].

\subsection{Enclosing structures in interior spaces}

The interior of a room is determined by architectural elements in structures and closures, including columns, walls, floors, and roofs. These elements make a building have a shape, carve out some of the space without limits, and set the pattern of the interior room [10]. The main elements of the building can be explained as follows, among others:

- Floor is a flat base area of an interior space that functions as a buffer supporting activities. The floor in a building must be designed to accept the load to be safe to use and durable.

- Walls are the most important and most important architectural elements in the building, which function as a supporting structure for the floor and ceiling and the levels above. The wall is the facade of the building that separates the space and protects the interior space in it and other functions that prioritize security values.

- The ceiling is part of the main element in the building, which has an important role as protection and forms the interior space and limits the space below it in a vertical dimension. The ceiling is supported by other building elements, namely the floor and walls, making it a unified building structure. 


\section{CERAMIC}

Ceramic products can be divided into two based on their function and use, namely ceramics as disposable objects or decorative objects. Disposable ceramics are ceramic objects with a physical function as a tool for daily life, such as eating and drinking utensils that prioritize their ergonomic value. In contrast, decorative ceramics are types of ceramic that function as displays such as interiors or other decorative objects where the aesthetics of these ceramic objects are the Important value [11].

From the beginning of their appearance till the present, ceramics have continued developing in terms of materials, production processes, combustion processes, functions, and uses. Ceramics, originally used as storage containers, have grown rapidly to various sectors, one of which is the industrial sector, supported by science, technology, and art. Now, ceramic products have high functional and commercial values.

In the production process of ceramic products, the term gypsum molding technique is known, which uses gypsum material as a mold to produce ceramic shapes that can be adapted to the selected design or model. This molding technique is divided into two types: slip casting and solid casting, where the difference between the two processes is the mixture of slip or liquid and solid clay.

\section{RESEARCH METHOD}

Practice-led research creates works of art and researches the creative process, which is then carried out by accumulating knowledge from works and research. In this research method, there are several processes, including honesty of practice and creative processes to prepare and finalize ideas, implement and test theories through practice, conduct experiments through a series of experiments or explorations, engage in fieldwork, and the process of documenting activities. In practice-based research, a creative model known as the iterative cycle web shows the flow of the research cycle starting from Research-led Practice, Academic Research, and Practice-led research [12]. The creative model can be explained into several cycle paths as follows:

- Idea generation

- Investigation and extrapolate from the idea

- Theorise ideas and develop techniques as method

- Application of theories and techniques to new creative work

- Develop chosen ideas

- Documentation of the artwork and its production

\section{RESULT}

In the idea generation process, the researcher deepens the understanding related to industrial style, which helps know things related to the visual characteristics of the interior theme. This understanding helps determine the shape, colour, composition of the production process to be carried out. Based on the results of observations and analysis of interior elements in several industrial themed cafes and restaurants in Tasikmalaya, it is known that the wall is the widest part of the room that is rarely explored and maximized. This part of the wall has the potential to be developed by applying interior products to increase the room's aesthetic value so that it can be an attraction for consumers. Based on this, other processes are then carried out, including an exploration process to develop ideas and determine production methods and techniques adapted to the concept of the Industrial theme.

\subsection{Shape exploration}

In designing the product, it is necessary to pay attention to the characteristics of the Industrial style, which seems geometric and less ornamental. The resulting product will be following the cafe concept and Industrial theme. An exploration process is carried out by looking for geometric shapes to determine the possibilities applied to the interior product. Spatial figures are geometric shapes with volumes that have specific properties, including having sides, edges, and vertices.

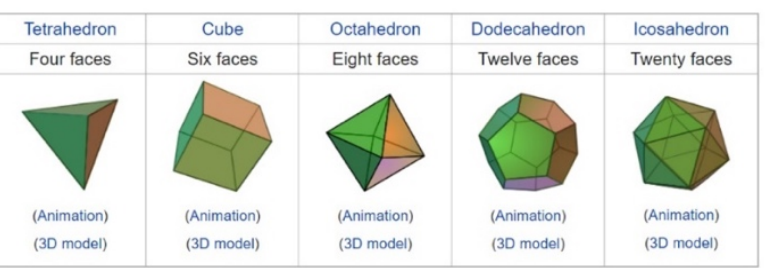

Figure 1 The five geometric forms of the platonic theory.

Among the existing spatial shapes, seven basic geometric shapes represent derivative forms in their groups: cubes, prisms, blocks, tubes, cones, rectangular pyramids, and spheres. In addition to the spatial structure, there is also a spatial structure part of the platonic theory coined by a Greek philosopher named Plato. This geometric space consists of the Tetrahedron, Cube, Octahedron, Dodecahedron, and Icosahedron shapes.

Based on the shape of spatial structures in the platonic theory, each has a unique spatial form. The five forms of the model consist of the simplest geometric shapes to those quite complex based on their order. The five geometrical shapes have vast potential, which becomes the inspiration for the shapes chosen to be developed into ceramic interior products. The next step is to make a simple sketch to see the possibilities of 
applying the shape as an interior product that utilizes the media of the room's walls to place the product.

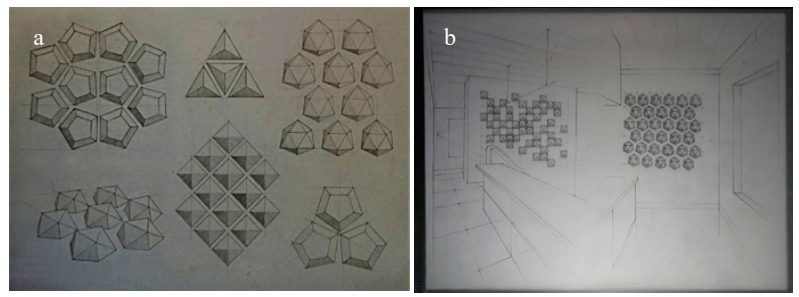

Figure 2 (a) Shape exploration; (b) Exploration of product application.

Based on the initial exploration results related to the shape of the product, the type of interior wall hanging product was chosen, which serves to increase the aesthetic value of a room that uses wall media for its application by utilizing the repeated arrangement of geometric shapes. To achieve this, the researchers used the gypsum molding technique, which is one of the ceramic production techniques that can produce repeatable and precise shapes. In addition, interior products in the form of wall hangings must be strong and light to maintain product safety and durability, so a material exploration process is needed to find the most appropriate material mix.

\subsection{Ceramic material exploration}

The criteria for the mixture of ceramic materials as wall hanging products must be plastic and easy to dry, adjusted to the production process through gypsum molding. To get the right mixture of ingredients, exploration is performed on several material mixtures to get the most suitable ingredients.

Table 1. Ceramic material exploration.

\begin{tabular}{|l|l|c|c|c|}
\hline No & Materials & Percentage & Shrinkage & Burning \\
\hline 1 & Feldpar & $30 \%$ & & \\
& Kaolin & $35 \%$ & $20 \%$ & $1230^{\circ} \mathrm{C}$ \\
& Kuarsa & $15 \%$ & & \\
& Sukabumi & $20 \%$ & & \\
\hline 2 & Feldpar & $25 \%$ & & $1230^{\circ} \mathrm{C}$ \\
& Kaolin & $40 \%$ & $18 \%$ & \\
& Kuarsa & $5 \%$ & & \\
& Sukabumi & $30 \%$ & & $1230^{\circ} \mathrm{C}$ \\
\hline 3 & Feldpar & $25 \%$ & & \\
& Kaolin & $40 \%$ & $18 \%$ & \\
& Kuarsa & $10 \%$ & & $1230^{\circ} \mathrm{C}$ \\
& Sukabumi & $25 \%$ & & \\
\hline 4 & Feldpar & $20 \%$ & & \\
& Kaolin & $30 \%$ & $16 \%$ & \\
& Kuarsa & $15 \%$ & & \\
& Sukabumi & $35 \%$ & & \\
& & & & \\
&
\end{tabular}

In this material exploration process, 4 material mixtures are made to find the material mixture that best fits the predetermined criteria. From the results found, the mixture of material number 3 is chosen because it can dry well in gypsum molds, and the drying material is tightly bound and easy to remove.

\subsection{Glaze exploration}

The application of glaze on ceramics will affect the ceramic surface's color, texture, and durability. Glaze exploration was performed to find a mixture of glaze materials that can provide clean white as the base color and a smooth texture. Later on, this ceramic wall hanging product can fit well into industrial interiors through monochromatic color adjustments, which are characteristic of the industrial style.

Table 2. Glaze exploration.

\begin{tabular}{|c|c|c|c|}
\hline No & Materials & Percentage & Burning \\
\hline 1 & $\begin{array}{l}\text { Kapur } \\
\text { Talc } \\
\text { Kaolin } \\
\text { Kuarsa } \\
\text { Feldpard } \\
\text { Zircon }\end{array}$ & \begin{tabular}{l|}
$15 \%$ \\
$12 \%$ \\
$8 \%$ \\
$22 \%$ \\
$43 \%$ \\
$10 \%$ \\
\end{tabular} & $1230^{\circ} \mathrm{C}$ \\
\hline 2 & $\begin{array}{l}\text { Kapur } \\
\text { Talc } \\
\text { Kaolin } \\
\text { Kuarsa } \\
\text { Feldpard } \\
\text { Zircon }\end{array}$ & $\begin{array}{l}15 \% \\
12 \% \\
8 \% \\
22 \% \\
43 \% \\
15 \% \\
\end{array}$ & $1230^{\circ} \mathrm{C}$ \\
\hline 3 & $\begin{array}{l}\text { Kapur } \\
\text { Talc } \\
\text { Kaolin } \\
\text { Kuarsa } \\
\text { Feldpard } \\
\text { Zircon }\end{array}$ & $\begin{array}{l}15 \% \\
12 \% \\
8 \% \\
22 \% \\
43 \% \\
20 \%\end{array}$ & $1230^{\circ} \mathrm{C}$ \\
\hline
\end{tabular}

From the results of simple glaze exploration, glaze mixture number 1 is chosen because each mixture produced a clean white color, and there was no significant difference in intensity between them. In mixture number 1 , the texture on the surface is smoother than mixture number 2 and 3, which has small lumps. In addition, the number 1 blend uses less zircon material, so it is more efficient.

\subsection{Production Process}

The process begins by making gypsum molds using infra board material and an adhesive glue gun. The infra board material is cut into four parts of the same size, about $15 \times 15 \mathrm{~cm}$. After that, the alternative models of the mold form were remade using duplex cardboard and placed on the surface of the mold base made of clay slab and then glued using clay by closing all the cavities at the bottom of the model. Then the infra board insulation that has been made previously is installed and adjusted so that the insulation can hold well and does not cause too much space at the base. The insulator is attached to the surface or base and then sealed with clay throughout the bottom and the inside to minimize the possibility of a leakage when pouring gypsum and strengthen the retainer to keep it in position until the molding process is done and the gypsum completely dries. 


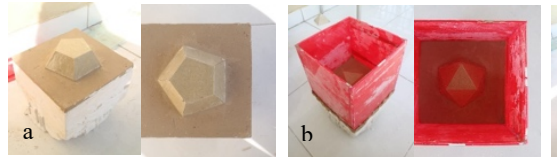

Figure 3 (a) mold model on clay surface; (b) Infra board installation; (c) poured gympsum.

After the model and insulation stick well, the gypsum material is made by mixing it with one-eighth of small plastic bucket water and about 400 grams of gypsum. After that, the gypsum is stirred until evenly distributed and feels slightly thickened for about 5 minutes, and then the gypsum mixture is poured entirely into the mold. The poured gypsum is allowed to stand for about 30 minutes until the gypsum becomes solid and stiff. Gypsum that is ready to be removed from the mold shows characteristics such as the hot surface has begun to warm up, the gypsum texture is not slippery and does not peel off easily. The finished gypsum mold is dried by drying and stored at room temperature for approximately 1 week so that the gypsum can dry well and evaporate all the water in it.

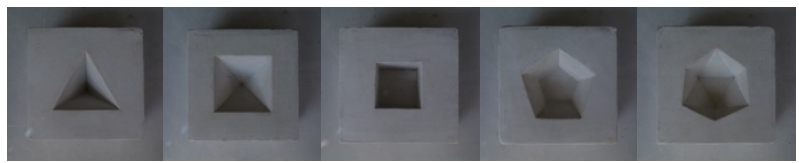

Figure 4 the five model of gypsums mold.

The production process starts by mixing previously selected clay material with sufficient water and stirred until mixed. The mixed ingredients then put into a small container for easy pouring process. Then the mixture of ingredients is poured into the mold until it slightly overflows and then let stand for about 5-10 minutes so that the surface of the gypsum mold can absorb most of the water from the mixture. After that, the mixture that overflows is removed using a sharp tool and a sponge until it is clean. This process is done to facilitate the process of removing the material from the mold. Finally, after being left for about 20 minutes from the initial process, by gently patting the surface of the gypsum, the dry clay mixture will come off easily.
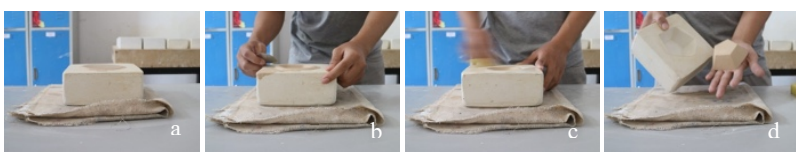

Figure 5 (a) Casting result; (b) Incising process; (c) Cleaning process; (d) Molded clay mixture.

In a day, the gypsum mold is capable of producing about 5-6 modules. With this amount, the mold can dry well overnight and continue the next day's production process. The molded clay mixture then left on a flat surface such as a wooden board for several days until it is dried, marked by the color of the material that turning white.

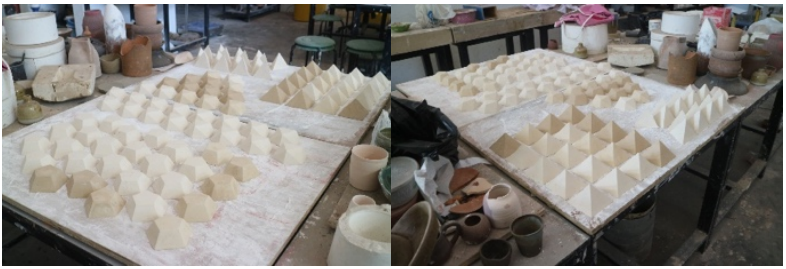

Figure 6 Drying process.

The dried material will then go through a bisque burning process at around 900 degrees Celsius which helps remove all moisture and compact the material to facilitate the process of applying glaze to the ceramic surface. In the next process, the surface of the module is cleaned using a wet sponge to remove dirt and reduce absorption. Then the module is dipped into the glaze for about 5 seconds with a tweezers tool.
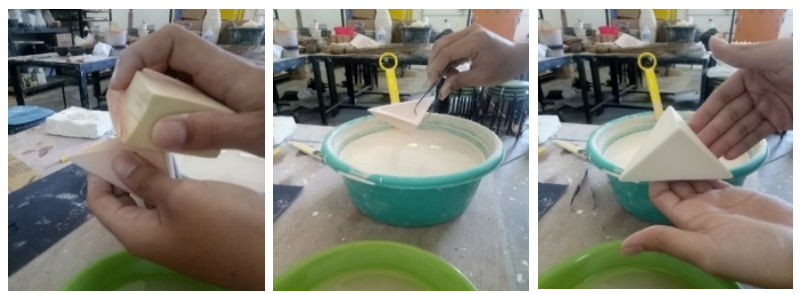

Figure 7 Cleaning process, dipping process and the result.

After the glaze application process is complete, the last process executes mature combustion at around 1230 degrees Celsius. This burning process is carried out slowly to avoid several types of damage to the ceramic module, such as deformation, so that the final result can be optimal. A series of good production processes in creating wall hanging ceramic products using gypsum casting techniques will produce strong and lightweight ceramic modules that can simplify applying products to walls using adhesives such as glue guns or double-sided tape.

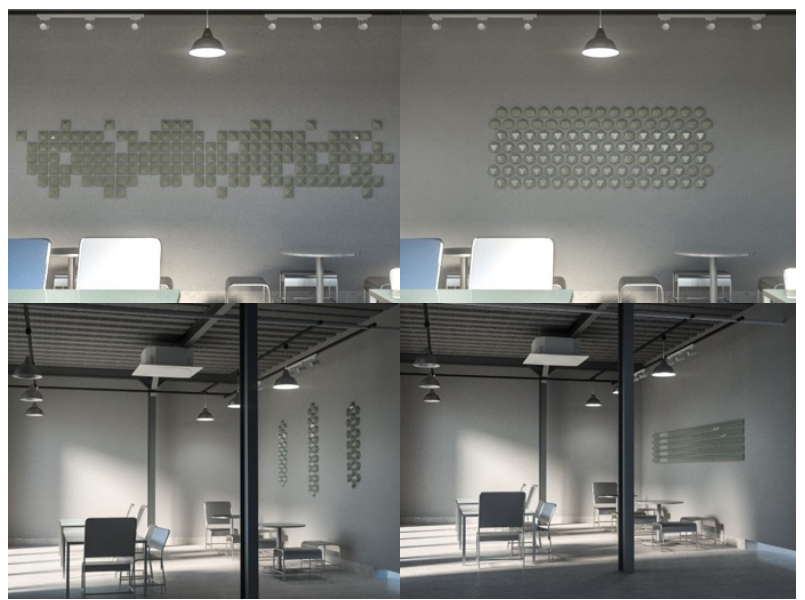

Figure 8 visualization of alternative wall hanging ceramic products. 


\subsection{Finishing Product}

The final result of ceramic products in the form of modules can be arranged and adapted to the needs of the existing space. Its application to the Industrial theme, which has exposed cement walls, makes it easier for the product to adhere appropriately using a glue gun or double-sided tape. The selection of shapes and colors in the product allows it to blend in with other interiors in the room.

\section{CONCLUSION AND DISCUSSION}

Based on the research conducted to produce wall hanging type ceramic interior products that can be applied to Industrial style themes, it can be done through the design process by adapting the basic geometric shapes and color, which are the architectural and interior elements characteristic of this theme. The production technique that uses gypsum molding is very suitable to produce geometric ceramic interior products because it streamlines production time and produces precise, repetitive module shapes according to product design. The advantages of the product in the form of a module arrangement simplify the application and composition process so that it can properly adjust to the need to increase the aesthetic value and attractiveness of the room.

The work produced in this research can still be developed to improve effectiveness and efficiency related to the production process and material testing and direct testing of fieldwork to ensure the suitability of the work with the themes raised in this study.

\section{ACKNOWLEDGMENTS}

The author would like to thank all parties who have helped and supported the research, especially my supervisor Dr. Gita Winata, S.Ds., M.Ds., for his support, immense knowledge, and motivation that guide me to complete this research.

\section{REFERENCES}

[1] B. Pink, W.T. Rahmawati, Sri Mulyani, Industri kuliner jadi penyumbang terbesar pertumbuhan ekonomi kreatif [Internet]. 2021 [14 July 2021]. Available https://nasional.kontan.co.id/news/sri-mulyaniindustri-kuliner-jadi-penyumbang-terbesarpertumbuhan-ekonomi-kreatif

[2] A. Larasati, Metodologi Penelitian-Bar\&Resto [Internet]. 2020 [19 July 2021]. Available from: https:/www.academia.edu/8008143/

[3] M. Putri, Irwansyah. Re-Desain Interior Cafe FAM'S FAM'S Bergaya Urban Industrial
[Internet]. 2020 [cited 18 July 2021]. Available from: http://e-journal.potensiutama.ac.id/ojs/index.php/FSD/article/view/703

[4] A.R. Putra, Pengaruh Sikap Konsumen Terhadap Desain Cafe dan Restoran pada minat berkunjung ulang. Yogyakarta: Universitas Sanata Dharma. 2018 .

[5] C.F. Zhang, G. Medvegy, J. Wang, Applied Reserach on Semiotics in Industrial Style Interior Design, in : Pollack Periodica, vol. 14(1), pp. 213222,2019

[6] R.A., Amini, A. Sumadyo, A. Marlina, Penerapan Prinsip Arsitektur Industrial dalam Produktifitas Ruang pada Solo Creative Design Center, in : SENTHONG, vol.2(2), pp.395-404, 2019.

[7] K.G. Aurellia, LTP AKADEMI KULINER DI SEMARANG tema desain : Arsitektur Kontemporer dengan Pendekatan Industrial. Unika Soegijapranata. 2016.

[8] M. Phung M, 5 karakteristik desain interior industrial [Internet]. Indonesia Mendesain. 2020. [cited 14 July 2021]. Available from: https://indonesiamendesain.com/2020/07/01/5karakteristik-desain-interior-industrial

[9] A.A. Wicaksono, E. Tisnawati, Teori Interior Sejarah, Konsep, Tata Cahaya, Tekstur \& Pola, Standarisasi, Istilah Interior. Jakarta: Griya Kreasi. 2014.

[10] F.D.K. Ching, Interior Design Illustrated Third Edition. Canada: John Wiley \& Sons, Inc. 1987.

[12] H. Barringer, C.S. Pasareanu, D. Giannakopolou, Proof rules for automated compositional verification through learning, in Proc. of the 2nd International Workshop on Specification and Verification of Component Based Systems, 2003.

[11] A. Astuti, Pengetahuan Keramik. Yogyakarta: Gadjah Mada University Press. 1997.

[12] H. Smith, T. Dean, Practice-Led Research, Research-Led Practice in the Creative Arts (Research Methods for the Arts and Humanities). United Kingdom: Edinburgh University Press. 2009. 